\title{
Kepemimpinan Kepala Madrasah Dalam Mengembangkan Sarana Prasarana MAN 3 Banyuwangi
}

\author{
Eko Budiywono ${ }^{1}$, Khoirul Fahmi Iskandar ${ }^{2}$ \\ e-mail: ekobeye31@gmail.com ${ }^{1}$, fahmiiskandar1997@gmail.com ${ }^{2}$ \\ Prodi Manajemen Pendidikan Islam \\ Institut Agama Islam Darussalam Blokagung Banyuwangi
}

\begin{abstract}
The research objectives of this study were (1) to determine the infrastructure in MAN 3 Banyuwangi, (2) to determine the leadership of the head of the madrasah in developing the infrastructure for MAN 3 Banyuwangi, and (3) to determine the supporting and inhibiting factors of the headmaster's leadership in developing the facilities. infrastructure in MAN 3 Banyuwangi. This research uses descriptive qualitative research. In this study, data collection techniques used observation, interviews, and documentation. Meanwhile, data analysis in this study used interactive analysis with 3 models of Miles \& Huberman, including: (1) data reduction, (2) data presentation and (3) decision making. The results of this study (1) the current madrasah infrastructure is classified as good and sufficient for the infrastructure needs, (2) the strategy of the madrasah principal in developing infrastructure by managing funds from the government and funds from infaq students or guardians of students, (3) ) Supporting factors in developing school infrastructure, principals and infrastructure have full policies in developing, maintaining and maintaining existing infrastructure and cooperation of all elements of the teacher council, employees and even students. Meanwhile, the inhibiting factor is due to the very limited budget owned by the school.
\end{abstract}

Keywords: Leadership of Madrasah Principals, Facilities and Infrastructure

\begin{abstract}
Abstrak
Tujuan Penelitian dari penelitian ini adalah (1) untuk mengetahui Sarana Prasarana di MAN 3 Banyuwangi, (2) untuk mengetahui kepemimpinan kepala madrasah dalam mengembangkan sarana prasarana MAN 3 Banyuwangi, dan (3) untuk mengetahui faktor pendukung dan penghambat kepemimpinan kepala madrasah dalam mengembangkan sarana prasarana di MAN 3 Banyuwangi. Penelitian ini menggunakan jenis penelitian deskriptif kualitatif. Dalam penelitian ini teknik pengumpulan data menggunakan observasi, wawancara, dan dokumentasi. Sedangkan analisis data dalam penelitian ini menggunakan analisis interaktif 3 model Miles \& Huberman meliputi: (1) Reduksi data, (2) penyajian data dan (3) pengambilan keputusan. Hasil penelitian ini (1) Sarana prasarana madrasah saat ini sudah tergolong baik dan mencukupi kebutuhan sarana prasarana, (2) Strategi yang dimiliki kepala madrasah dalam mengembangkan sarana prasarana dengan mengelola dana dari pemerintah dan dana dari infaq peserta didik atau pun wali murid, (3) Faktor Pendukung dalam mengembangkan sarana prasarana sekolah, kepala sekolah dan bidang prasarana memilki kebijakan penuh dalam mengembangkan, menjaga dan merawat sarana prasarana yang ada serta kerjasama seluruh elemen dewan guru, karyawan bahkan siswa. Sedangkan Faktor Penghambatnya karena anggaran yang dimiliki sekolah yang sangat terbatas.
\end{abstract}

Kata Kunci : Kepemimpinan Kepala Madrasah, Sarana dan Prasarana

Kepemimpinan Kepala Madrasah Dalam Mengembangkan Sarana Prasarana MAN 3 Banyuwangi

Eko Budiywono, Khoirul Fahmi Iskandar 


\section{A. Pendahuluan}

1. Latar Belakang

Kepemimpinan adalah merupakan suatu kemampuan dan proses mempengaruhi, mengkoordinir dan mengendalikan orang lain yang ada hubunganya dengan pengembangan ilmu pengetahuan dan pendidikan serta agar kegiatan yang dilaksanakan lebih efisien dan efektif dalam pencapaiam tujuan-tujuan pendidikan dan pengajaran. Sedangkan menurut Syamsu (32:2017) kepemimpinan yaitu seseorang yang memmpin, berarti sifat yang harus dimiliki oleh seorang pemimpin. Oleh karena itu, kepemimpin bisa diartikan sebagai kemampuan khusus yang dimiliki seseorang untuk mempengaruhi manusia dalam melakukan tugas ataupun tidak melakukan tugas suatu pekerjaan

Pemimpin pendidikan dalam hal ini adalah kepala madrasah sebagai orang yang bertanggung jawab terhadap pelaksanakaan pendidikan dan pengajaran dilembaga pendidikan, kepala madrasah harus memiliki kesiapan dan kemampuan untuk membangkitkan semangat kerja sosial. Karena seorang pemimpin juga harus menciptakan suasana yang kondusif, aman, nyaman, tentram, menyenangkan, dan penuh semangat dalam bekerja bagi para pekerja dan bagi pelajar. Sehingga pelaksanaan pendidikan dan pengajaran dapat berjalan tertib, lancar dalam mencapai tujuan yang diharapkan. Kiranya dasar berpijak yang menjadi patokan adalah UUD 1945 Pasal 31 ayat 1 yang menyatakan bahwa "tiap-tiap warga Negara berhak mendapatkan pengajaran". Undang-undang ini dilandasi oleh keinginan untuk memelihara dan menjaga kedaulatan manusia yang memiliki hak belajar. Oleh karenanya tiap -tiap warga Negara dapat menerima pengajaran bila seluruh sarana prasarana mencukupi dan memadahi.

Menurut Erjati Abas (05:2017) "Melaksanakan kepemipinan kepala madrasah dengan baik, akan menciptakan iklim organiasi lembaga madrasah yang kondusif'. Maka dari itulah diharapkan kepemimpinan kepala madrasah yang baik dapat menghasilkan pendidikan yang berkualitas. Dalam proses Kepemimpinan Kepala Madrasah Dalam Mengembangkan Sarana Prasarana MAN 3 Banyuwangi

Eko Budiywono, Khoirul Fahmi Iskandar 
belajar mengajar, juga akan berhasil jikalau dalam suatu lembaga pendidikan memiliki fasilitas belajar yang memadahi. Sarana prasarana yang tercukupi yang akan mendorong terhadap kesemangatan peserta didik dalam menuntut ilmu. Sehingga tujuan yang dikehendaki subyek belajar itu akan tercapai.

MAN 3 Banyuwangi merupakan salah satu madrasah negri ternama dikabupaten Banyuwangi, bahkan madrasah itu tergolong madrasah yang sangat berkualitas. adapun salahsatu bentuk kualitasnya yang sangat bagus dengan memiliki prestasi meraih penghargaan juara 1 akreditasi madrasah tingkat profinsi jawa timur. Tentu saja keberhasilan itu atas upaya oleh berbagai pihak khusunya kepala madrasah dalam mengembangkan lembagan madrasahya, salah satunya dalam mengembangkan sarana prasarana yang memadahi. Namun, karena kualitas sekolah yang sangat bagus, sehingga tingkat minat masyarakat pada MAN 3 Banyuwangi sangat pesat, sehingga sarana prasarana yang sudah sangat baik, dituntut situasi untuk lebih mencukupi karena banyaknya siswa ataupun siswi yang menuntun ilmu dimadrsah itu, sehingga menjadi tugas besar untuk lembaga madrasah dalam menyelesaikan permasalahan baru itu, sehingga proses belajar mengajar dapat berjalan sesuai harapan dan mendapatkan hasil puncak kesuksesan dari visi misi lembaga madrasah.

Sarana prasarana sangatlah berpengaruh terhadap peserta didik dalam menjalani kegiatan-kegiatan baik dalam proses kurikuler maupun ekstra kurikuler, para siswa pasti akan terhambat dan dapat mengurangi kesemangatan peserta didik dalam menuntut ilmu, hanya karena fasilitas sarana prasana yang kuang memadahi. Dengan berpedoman pada Permendiknas No 24 Tahun 2007 Pasal 2 tentang "penyelenggaran bagi satu kelompok pemukiman permanen dan terpencil yang penduduknya kurang daari 1000 (seribu) jiwa dan tidak bisa dihubungkan dengan kelompok yang lain dalam jarak tempuh 3 kilo meter melalui lintasa jalan kaki yang tidak membahayakan dapat menyimpangi standar sarana prasarana sebagaimana diatur dalam peraturan mentri ini.

Kepemimpinan Kepala Madrasah Dalam Mengembangkan Sarana Prasarana MAN 3 Banyuwangi

Eko Budiywono, Khoirul Fahmi Iskandar 
Dalam permendiknas yang telah dipaparkan, bahwasanya proses belajar mengajar tidak akan efektif, kondusif, aktif dan menyenangkan kecuali sarana prasarana memenuhui kebutuhan peserta didik, maka dari itu kepala madrasah sebagai menejerial dan penentu kemajuan madrasahnya, juga harus memfungsikan secara maksimal mampu memimpin madrasah dengan mengarah pada pencapaian tujuan yang maksimal demi meningkatkan kualitas dan mutu pendidikan dimadrasahnya, yang tentu saja akan berimbas kepada kualitas kelulusan anak didik sehingga bisa membanggakan dan menyimpan masa depan yang cerah. Karena itu kepala madrasah harus memiliki wawasan keahlian menejerial, dan juga pengetahuan yang luas tentang tugas dan fungsinsya sebagai kepala madrasah. Dan juga harus memiliki langkah-langkah yang berupa strategi, guna untuk menjadikan lembaga pendidikan yang memadai.

2. Rumusan Masalah

1) Bagaimana sarana prasarana di MAN 3 Banyuwangi?

2) Bagaimana kepemimpinan kepala madrasah dalam mengembangkan sarana prasarana MAN 3 Banyuwangi ?

3) Apa faktor pendukung dan penghambat kepemimpinan kepala madrasah dalam mengembangkan sarana prasarana di MAN 3 Banyuwangi ?

3. Tujuan Penelitian

1) Untuk mengetahui Sarana Prasarana di MAN 3 Banyuwangi.

2) Untuk mengetahui kepemimpinan kepala madrasah dalam mengembangkan sarana prasarana MAN 3 Banyuwangi.

3) Untuk mengetahui faktor pendukung dan penghambat kepemimpinan kepala madrasah dalam mengembangkan sarana prasarana di MAN 3 Banyuwangi.

4. Manfaat Penelitian

Hasil penelitian ini diharapkan dapat bermanfaat tau berguna bagi berbagai pihak, anara lain.

1. Manfaat Akademis dari penelitian ini adalah untuk mengembangkan ilmu yang telah diperoleh dibangku kuliah melalui penelitian tentang Kepemimpinan Kepala Madrasah Dalam Mengembangkan Sarana Prasarana MAN 3 Banyuwangi Eko Budiywono, Khoirul Fahmi Iskandar 
kepemimpinan kepala madrasah dalam mengembangkan sarana prasarana MAN 3 Banyuwangi.

2. Manfaat umum diharapkan hasil dari penelitian ini menjadi acuan, evaluasi, serta menambah paradigma baru bagi sekolah dalam upaya mengembangkan sarana prasarana pendidikan dengan memanfaatkan keterlibatan seluruh komponen yang ada disekolah, khususnya kepala madrasah yang merupakan seorang manajer dalam upaya pengembangan sarana prasarana pendidikan ini sehngga tujuan pembelajaran dapat tercapai dengan keriteria yang diharapkan.

3. Manfaat untuk pembaca sebagai salah satu sumber untuk memperkaya pemahaman para pelaksana dilapangan. Khususnya kepala madrasah, tenaga pendidik dan kependidikan yang terlibat langsung maupun tidak langsung dalam upaya pengembangan sarana prasarana pendidikan.

\section{B. Landasan Teori}

1. Kepemimpinan

Kepemimpian atau kegiatan memimpin merupakan usaha yang dilakukan oleh seseorang dengan segenap kemampuan yang dimiliki untuk mempengarui dan menggerakkan yang dipimpin supaya mereka mau bekerja dengan penuh tanggung jawab. Allah swt. Berfirman dalam Al-Qur'an surat An-Nisa ayat 58

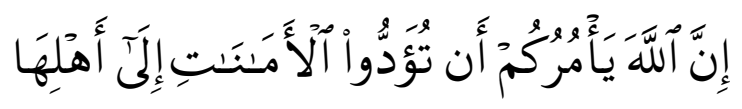

Artinya: "sesungguhnya Alloh Swt. Menyerukan kepada kalian semua untuk menyampaikan amanat kepada orang yang berhak menerimnya”.

Ayat diatas memerintahkan kepada seluruh manusia utuk mengemban amanah sebaik mungkin, dengan melaksanakan perintah Alloh swt. Dan menjauhi larangannya, termasuk korupsi yang telah dilakukan oleh para tikus

Kepemimpinan Kepala Madrasah Dalam Mengembangkan Sarana Prasarana MAN 3 Banyuwangi

Eko Budiywono, Khoirul Fahmi Iskandar 
Negara atau koruptor pada bangsa ini, tindakan ini sangat merugikan berbagai belah pihak khususnya suatu yang dipimpin seperti lembaga pendidikan/lembaga madrasah. Sehingga visi misi suatu madrasah dapat dicapai sesuai yang diharapkan. Menurut Lembaga Administrasi Negara (2008:7) "kepemimpinan merupakan suatu perkara yang dilakukan individu terhadap orang lain dalam situasi kondisi tertentu yang diarahkan kepada suatu tujuan melalui komunikasi berbagai pihak yang dibutuhkan”.

2. Faktor -faktor yang mempengaruhi pemimpin.

Dalam menjalankan tugas-tugasnya sebagai pemimpin suatu organisasi atau lembaga dalam mengembangkan pendidikan, Menurut Permadi D. (2007:20) seseorang yang berprofesi sebagai pememiliki tanggung jawab kepada orang banyak yang artinya sebagai pemimpin pendidikan dipengaruhi oleh faktor-faktor yang mewarnai kepemimpinannya.

a. Pengalaman masa lampau, karena hal ini memiliki nilai-nilai pengalaman dan keberanian yang sangat berpengaruh terhadap gaya kepemimpinannya.

b. Keinginan yang tinggi dan kepribadian atasan.

c. Timbal balik tingkah laku seorang yang dipimpin kepada pemimpin memiliki pengaruh besar terhadap manager.

d. Kebijakan dan tindakan seorang pemimpin mempengaruhi kesemangatan bawahan.

e. Kebutuhan tugas, setiap tugas karyawan atau bawahan sangat mempengaruhi dalam kepemimpinan.

f. Faktor lingkungan, baik rekan seperjuangan ataupun kondisi tempat.

Hal lain juga dikemukakn oleh Arifin D. (2007:20) sebagai berikut:

a. Kondisi ekonomi dan adanya konsep pendidikan sebagai pengaruh dalam kepemimpinan.

b. Ciri khas sekolah atau lembaga.

c. Kepribadian sifat karakter seorang pemimpin.

d. Perubahan keberhasilan atau kegagalan.

Kepemimpinan Kepala Madrasah Dalam Mengembangkan Sarana Prasarana MAN 3 Banyuwangi

Eko Budiywono, Khoirul Fahmi Iskandar 
Disamping itu pula menurut wahdjo sumidjo (2010:50) juga mengemukakan beberapa factor-faktor yang pada umumnya sangat dominan mempengaruhi kepemimpinan.

a. Bakat atau kemampuan yng dimiliki seorang pemimpin untuk menjadi seorang pemimpin yang baik.

b. Sifat-sifat kepribadian pemimpin.

c. Sifat-sifat kepribdian pengikut.

d. Sanksi-sanksi yang ada pada kebijakan seorang pemimpin.

3. Fungsi-Fungsi Kepemimpinan

Setelah mengetahui tentang kepemimpinan tentu tidak kalah penting untuk mengetahui fungsi-fungsinya Menurut Syamsu (2017:53) fungsi kepemimpinan adalah:

1. Penyusuna berbagai hal termasuk yang akan dilakukan, seperti pengarahan, pengendalian penilaian atau laporan.

2. Sebagai motivator seorang yang bekerja sebagai karyawan atau bawahan agar memiliki etos kerja yang kuat.

3. Membimbing dan mengarahkan agar selalu bertanggung jawab terhadap pekerjaan masing-masing sebagai karyawan.

4. Selalu bertanggung jawab atas karyawan bekerja selalu yang efektif dan efisien.

5. Menjadikan suatu kepemimpinan yang harmonis.

6. Mengatur manajerial dengan baik.

7. Aktif dalam kreatifitas ide-ide sebagai meanajerial.

8. Penghubung dengan pihak luar dalam sebagai fungsi kepemimpinan.

Untuk menjadikan kepemimpinan yang lebih baik, maka harus menggunakan fungsi-fungsi kepmimpinan dengan sepenuhnya. Menurut Novianty Djafri (2017:52) “fungsi kepemimpinan adalah memandu, menuntun, membimbing, membangun, memberi motivasi kerja, mengemudikan organisasi, menjalin jaringan-jaringan para pengikutnya

Kepemimpinan Kepala Madrasah Dalam Mengembangkan Sarana Prasarana MAN 3 Banyuwangi

Eko Budiywono, Khoirul Fahmi Iskandar 
kepada sasaran yang ingin dituju sesuai dengan ketentuan waktu dan perencanaan.

4. Kepala Madrasah

Menurut Wahdjosumidjo (2010:83) "kepala madrasah berarti tugas yang diberikan kepada seorang guru fungsional suatu lembaga pendidikan untuk memimpin dan melaksanakan wewenang kebijakanya dalam mengembangkan suatu lembaga pendidikan, sehingga terjadi interaksi antara guru dan peserta didik dalam proses belajar mengajar”. Dari pemaparan yang diberikan ilmuan diatas, kesimpulan yang dapat diambil yaitu kepala madrasah merupakan seorang guru yang diberikan tugas yang dobel tidak hanya sebagai panutan peserta didik atau seorang yang memberikan, menularkan ilmunya dikelas, akan tetapi mejadi patokan penunjang kesuksesan keseluruhan sehingga menjadi panutan oleh berbagai pihak baik guru, karyawan dan peserta didik dilembaga yang dipimpin.

5. Tugas Dan Fungsi Kepala Madrasah

Setiap sekolah atau madrasah, pasti memiliki visi dan misi yang menjadi patokan dari tujuan suksesnya suatu lembaga pendidikan, yang mana digerakan oleh seorang yang tidak sembarangan, yang dipilih dan diangkat menjadi orang yang dipercaya dapat menjalankan tugas-tugasnya sebaik mungkin yaitu kepala madrasah, maka dari itu seorang yang sudah dipercaya oleh berbagai pihak harus menjalankan tugas-tugasnya dengan baik sesuai citacita suatu lembaga pendidikan. Menurut Peraturan Mentri Pendidikan Nasional Nomor 13 Tahun 2007 tentang standar kepala sekolah, dijelaskan bahwa, lima dimensi kompetisi kepala sekolah yang harus diketahui dan dilakukan antara lain komponen kepribadian, kewirausahaan, manajerial, supervisi, dan sosial. Dari beberapa aspek diatas, ditekankan untuk kepala madrasah benar-benar harus mampu menjalankan tugasnya sehingga cita-cita dari visi misi lembaga dapat didapatkan.

Dinas pendidikan juga mengemukakan dan menetapkan, bahwa seorang kepala madrasah untuk mampu melaksanakan tugasnya sebagai Kepemimpinan Kepala Madrasah Dalam Mengembangkan Sarana Prasarana MAN 3 Banyuwangi Eko Budiywono, Khoirul Fahmi Iskandar 
manajer, edukator, administrator, dan supervisor. Selanjutnya, dari melihat perkembangan dan kebutuhan masyarakat dalam gaya baru manajemen pendidikan, seorang pemimpin harus selalu menyesuaikan sesuai dengan yang diharapkan oleh masyarakat. Dengan hal tersebut, seorang pemimpin akan merasakan hal-hal baru yang akan meningkatkan kinerjanya sesuai perkembangan zaman dalam memimpin lembaga pendidikan. Maka dari itu, poin-poin diatas tidak dapat hanya dipahami dan dimengerti oleh kepala madrasah, bahkan harus dikerjakan, dilakukan dengan keseluruhan. Akan tetapi seorang kepala madrasah harus berani dan memiliki keinginan yang sangat kuat untuk menjalankan, melaksakan dalam hal yang nyata dari materi poin yang diketahui untuk diamalkan disekolah yang ia pimpin.

Menurut Erjati Abbas (2017:5) "kepemimpinan kepala madrasah sebagai kekuatan dinamik yang dapat menghasilakn tujuan dalam lembaga pendidikan". Selain itu, kapasitas seorang kepala madrasah sangat menentukan dalam melaksanakan tugas-tugasnya dalam proses administratif yang benar dan baik. kemampuan kepala madrasah dalam audit program dan kegiatankegiatan disekolah tentu tidak akan dihasilkan kecuali telah melakukan pengarahan demi meningkatkan kapasitas melakukan pekerjaan sesuai profesinya. Dari pemaparan diatas, dapat ditarik kesimpulan bahwa, tahun ketahun perkembangan zaman sangatlah cepat yang ada pada masyarakat era modern, beberapa pekembangan kebijakan program yang ada, tentu tidak akan cukup untuk dalam lembaga sekolahnya, maka dari itu seorang kepala madrasah dituntut untuk mengembangkan lembaga pendidikan dengan mengikuti sesuai perubahan zaman yang ada. Sehingga dapat melaksanakan tugas dan fungsi kepala madrasah dengan baik sesuai tujuan.

6. Gaya Kepemimpinan Kepala Madrasah

Kepala madrasah merupakan pemimpin dan sekaligus menejer pada suatu instansi pendidikan. Ia termasuk salah satu kunci jaminan berhasil atau tidaknya suatu instansi atau organisasi mencapai tujuan yang telah direncanakan. Sudah pasti, kinerja kepala madrasah tersebut akan menjadi Kepemimpinan Kepala Madrasah Dalam Mengembangkan Sarana Prasarana MAN 3 Banyuwangi Eko Budiywono, Khoirul Fahmi Iskandar 
barometer bagi komunitas-komunitas lain, baik internal ataupun eksternal, dalam menjalankan tugas-tugas kewajibanya. Menurut Wahjosumidjo (2010:101) "keberhasilan madrasah dapat dilihat dari keberhasilan kepala madrasah". Maka dari itu, adanya kepemimpinan kepala madrasah yang efektif sesuai rencana yang bertujuan untuk mencapai cita-cita sekolah, menjadi syarat wajib yang harus dimiki kepala madrasah dalam memimpin lembaga pendidikanya. Maka berkaitan dengan hal tersebut, gaya kepemimpinan kepala madrasah sangat berpengaruh terhadap apa yang telah dilakukan oleh kepala madrasah kepada lembaga pendidikanya. Dari berbagai macam gaya yang ada, gaya kepemimpinan situasional akan lebih fleksibel unruk menjalankan operasional sekolah yang ada.

Menurut Mulyasa (2013:20) "gaya kepemimpinan dengan melihat situasi dan kondisi, merupakan gaya yang terbaik dilakukan kepala madrasah dalam menghadapi masalah”. Berbagai gaya antara lain demokratis, ataupun kharismatik memiliki kelebihan dan kekurangan masing-masing dalam penerapan atau implementasinya, sehingga sulit untuk membedakan mana yang terbaik darinya. Maka dari itu gaya melihat situasi dan kondisilah yang paling tepat dan terbaik dari beberapa gaya keemimpinan kepala madrasah untuk menghadapi situasi ataupun masalah sekolah.

Menurut Lembaga Administrasi Negara (2008:38) "gaya kepemimpinan kepala madrasah dengan melihat situasi lahir karena dipengaruhi faktor-faktor lain, diantaranya visi-misi sekolah, sifat pekerjaan kepemimpinan, dan lingkungan yang ia pimpin”. Dari pemaparan tentang gaya kepemimpinan kepala madrasah. Dapat diambil kesimpulan bahwa, seorang pemimpin dalam mengembangkan dan menjadikan cita-cita madrasahnya menjadi terwujud dengan cara memiliki gaya dalam kepemimpnan, karena keberhasilan suatu madrasah terdapat pada keberhasilan kepala madrasah, dan keberhasilan kepala madrasah juga dikarenakan gaya-gaya dalam memimpin kepala madrasahnya.

7. Sarana Prasarana Kepemimpinan Kepala Madrasah Dalam Mengembangkan Sarana Prasarana MAN 3 Banyuwangi Eko Budiywono, Khoirul Fahmi Iskandar 
Menurut Rusdiana (2015:212) prasarana pendidikan merupakan, fasilitas sekolah yang digunakan secara tidak langsung dalam menunjang peserta didik dalam mencari ilmu. Menurut Kompri (2014:193) mengenai sarana prasarana ini, akan dijelaskan dan dibahas dengan cara menjadi satu atau tidak dipisahkan, karena keduanya memiliki hubungan yang sangat erat yang sangat sulit dibedakan dan dipisahkan. Prasarana dalam pembahasan ini dapat dicontohkan yakni taman sekolah, kantin, lapangan, toilet, yang menjadi kebutuhan dan tempat belajar akan berubah menjadi sarana pendidikan karena menjadi kebutuhan secara langsung dalam mewujudkan proses pembelajaran berlangsung.

8. Jenis-Jenis Sarana Prasarana

Dari pemaparan diatas, sarana prasarana dapat diketahui dan akan diklarifikasi sebagai berikut:

1. Lahan yang berarti, tempat atau lahan yang akan dijadikan sekolah yang membutuhkan bagunan berbagai ruangan.

2. Ruangan yang berarti, bangunan-banguna berupa tempat yang dipisahkan oleh tembok, yang menjadi tempat proses belajar mengajar, manajerial, administrasi, laboratorium dan lain sebagainya.

3. Prabot yang berarti kelengkapan sebagai pembantu suatu proses belajar mengajar.

4. Alat yang berarti, sesuatu yang harus digunakan untuk menjalankan suatu pekerjaan atau kegiatan.

5. Sarana olah raga yang harus dimiliki untuk mengtahui cara hidup sehat melalui kegiatan-kegiatan baik didalam ruangan atau diluar ruangan.

Menurut Rusdiana (2015:214) akan lebih rinci sarana prasarana dapat digolongkan sebagai berikut:

1. Fungsi tidak secara langsung.

Contoh: tanah, pagar, tanaman, lapangan, bangunan.

2. Fungsi secara langsung.

Contoh: alat-alat proses belajar mengajar.

Kepemimpinan Kepala Madrasah Dalam Mengembangkan Sarana Prasarana MAN 3 Banyuwangi

Eko Budiywono, Khoirul Fahmi Iskandar 
9. Standarisasi Sarana Prasarana

Dalam peraturan yang dikeluarkan pemerintah melalui mentri pendidikan menerbitkan Peraturan Pemerintah No. 242007 tentang Standar Sarana Prasarana. Standar sarana prasarana berdasarkan PP No.19 Tahun 2005 tentang standar nasional yang berkaitan dengan ruangan dalam belajar, tempat olahraga, tempat ibadah, perpustakaan, laboratorium, tempat bermain, tempat kreasi peserta didik, serta keperluan lain yang menjadikan kebutuhan peserta didik dalam proses belajar mengajar. Menurut Barnawi (2016:86) "kata standarisasi bukan berasal dari kata standard+isasi, akan tetapi kata standarisasi merupakan bahasa asning yang telah diserap dalam bahasa Indonesia yang memiliki arti penyesuaian kualitas atau bentukdengan beberapa pedomanstandaryang telah ditetapkan oleh pemerintah melalui mentri penddikan".

Menurut Teguh Triwiyanto (2010:111-112) “dalam upaya memenuhi standarisasi sekolah, harus melakukan kegiatan-kegiatan yakni meningkatkan kepekaan terhadap seluruh pihak dalam perawatanya, dapat mengelola dengan baik, merenovasi yang perlu diperbaiki, serta meningkatkan keamanan dan kenyamanan sarana prasarana". Menurut M. Arifin (2016:86) seluruh madrasah diindonesia harus memenuhi 8 jenis standarisasi yang telah ditetapkan oleh pemerintah antaralain: (1) standar isi; (2)standar proses; (3)standar kompetesi kelulusan; (4) standar tenaga pendidik dan karyawan; (5) standar sarana prasarana; (6) standar pengelolaan; (7) standar pembiayaan; (8) standar penilaian pendidikan.

Akan tetapi, pada kenyataanya setiap sekolah ataupun lembaga pendidikan selalu berfokus dalam pengadaan sarana prasarana saja, sehingga dalam proses perawatan banyak yang menghiraukan dan tidak memperdulikanya. Padahal setiap fasilitas sarana prasarana yang ada disekolah, pasti memiliki jangka kelayakan pemakain dalam bentuk kenyamanan bahkan keamanannya. Hal inilah yang seharusnya disadari dan diperhatikan secara khusus oleh pihak sekolah melalui manajemenya seperti: Kepemimpinan Kepala Madrasah Dalam Mengembangkan Sarana Prasarana MAN 3 Banyuwangi Eko Budiywono, Khoirul Fahmi Iskandar 
membuat peraturan yang berlaku untuk semua pihak baik guru, karyawan. Serta peserta didik disekolah. Serta selalu memberikan motivasi dan pengarahan kepada semua pihak untuk menjadikan dirinya peduli terhadap lingkungan yang bertujuan menjaga dan merawat sarana prasarana sekolah, sehingga proses belajar mengajar selalu dalam kondisi aman dan nyaman.

\section{Metode Penelitian}

Penelitian ini menggunakan jenis penelitian deskriptif kualitatif yakni penelitian yang bersifat mendeskripsikan hasil penelitian sebagai jawaban dari rumusan masalah penelitian. Pada penelitian ini peneliti mengkonsentrasikan pada peran public relation dalam meningkatkan reputasi di MAN 3 Banyuwangi. Lokasi penelitian ini ialah Madrasah Aliyah Negeri 3 Banyuwangi. Sumber data yang digunakan dalam penelitian ini ada dua yaitu: sumber data primer dan sekunder. Sumber data primer adalah sumber data yang dipakai oleh peneliti dalam menghimpun data utama yakni pengelola MAN 3 Banyuwangi sebagai nara sumber utama dan observasi langsung di lembaga untuk mendapatkan data berupa kondisi nyata masalah penelitian. Sedangkan sumber data sekunder didapat dari bagian tata usaha untuk mendapatkan data terkait administrasi dan data pendukung penelitian lainnya. Dalam penelitian ini teknik pengumpulan data menggunakan observasi, wawancara, dan dokumentasi. Sedangkan analisis data dalam penelitian ini menggunakan analisis interaktif 3 model Miles \& Huberman meliputi: (1) Reduksi data, (2) penyajian data dan (3) pengambilan keputusan.

\section{Hasil Penelitian}

1. Tugas dan Fungsi Kepala Madrasah MAN 3 Banyuwangi

MAN 3 Banyuwangi merupakan salah satu sekolah yang ada di kawasan Banyuwangi, yang bertepatan dikecamatan Srono, yang dipimpin oleh Drs. H. Kosim, M.Pd.I, M.Ag. seorang pemimpin yang telah diberikan amanah besar atas tanggung jawabnya memimpin serta mengelola tugas yang sangat beragam untuk madrasahnya. Membutuhkan jiwa kepemimpinan serta Kepemimpinan Kepala Madrasah Dalam Mengembangkan Sarana Prasarana MAN 3 Banyuwangi Eko Budiywono, Khoirul Fahmi Iskandar 
tanggung jawab yang baik untuk menjadikan madrasah yang bermutu sehingga apa yang menjadi tujuan daripada madrasah dapat tercapai. Adapun tanggung jawab kepala madrasah dapat dilihat dari melaksanakan tugas dan kepemimpinanya terhadap madrasah yang ia pimpin. Hal tersebut sesuai yang telah dikemukakan oleh Ibu Nur Dwi Utami, S.Pd. Sebagai pengelola madrasah dibidang sarana prasarana.

"Tugas kepala madrasah sendiri adalah melakukan kebijakaan atas hak preogratifnya dengan dibantu seluruh puhak sekolah demi mengembangkan madrasah sesuai dengan tujuan dari beberapa hal yang telah direncanakan".

Selain itu, beliau juga memaparkan bahwa seorang kepala madrasah harus memiliki beberapa hal positif yang maksimal baik dari segi sikap, kualifikasi, maupun kompetisi secara pasti apabila kedepanya dalam mimpin menginginkan program-programnya dapat berjalan dengan baik dan lancar. Karena menurut beliau, untuk memimpin MAN 3 Banyuwangi ini diperlukan seorang pemimpin yang benar-benar memiliki kualitas yang sangat baik, dengan memiliki jiwa kepemimpinan yang kuat, mempunyai kesungguhan memimpin sepenuh hati, fokus terhadap tugas-tugasnya sebagai kepala madrasah. Karena dalam memimpin madrasah ini memiliki banyaknya rintangan dan tantangan yang harus dihadapi, apalagi dalam mendirikan serta mengembangkan madrasahpun tidak semudah membalikan telapak tangan. Selain itu, seorang kepaa madrasah juga harus konsisten dengan menjadi suri tauladan yang baik untuk semua pihak, khusunya dalam menjalankan aturan tata tertib yang direncanaran dan dibuatnya.

Menurut E. Mulyasa (2011:99). Mengatakan bahwa, “ kepala sekolah memiliki beberapa fungsi antara lain, manajer, edukator, supervisor, administrator, leader, innovator, motivator, mediator dan figure. Dari pemaparan diatas, tugas kepala madrasah dapat disimpulkan saangatlah banyak ragamnya antara lain, sebagai manajer, figur, mediator, supervisor, administrator, leader, innovator, motivator dan edukator. Apalagi dalam memimpin MAN 3 Banyuwangi diharuskan memiliki jiwa kepemimpinan

Kepemimpinan Kepala Madrasah Dalam Mengembangkan Sarana Prasarana MAN 3 Banyuwangi

Eko Budiywono, Khoirul Fahmi Iskandar 
yang sangat kuat, ikhlas dalam bekerja, memiliki keinginan yang sangat besar untuk memajukan madrasahnya, serta menjadi suri tauladan untuk semua pihak baik dari dewan guru, karyawan dan peserta didik. Sebagai kepala madrasah juga harus lebih patuh terhadap peraturan-peraturan yang ada, baik menjalankan dari pada kebijakanya serta menjauhi semua larangan yang telah ada. Sebagai contoh dalam menjaga dan merawat sarana prasarana yang ada, sehingga kepala madrasah tidak hanya mengadakan, memfasilitasi madrasahnya dengan memiliki sarana prasarana yang memadahi, akan tetapi juga merawat serta menjaga sarana prasarana yang ada.

2. Penyusunan Rencana Kebutuhan MAN 3 Banyuwangi

Setiap sekolah dalam mengembangkan sarana prasarana pasti memiliki langkah-langkah yang diperlukan untuk membantu berjalanya kegiatan yang ingin dicapainya, antara lain mengidentifikasi permasalahan, melakukan hasil dari masalah yang ditemukan dalam mengembangkan sarana prasarana. Namun sebelum melangkah pada kegiatan inti dari pengembangan sarana prasarana, sekolah harus memperhatikan langkah yang sangat penting demi mewujudkan berjalanya kegiatan tersebut yakni perencanaan kebutuhan sarana prasarana. Dalam persoalan ini, kepala madrasah MAN 3 Banyuwangi selalu memecahkan dan merundingkan penyusunan rencana kebutuhan sekolahnya terhadap orang-orang yang telah diberi kepercayaan untuk membantu tugasnya dalam mengembangkan sarana prasarana, antaralain orang-orang tersebut yaitu bidang sarana prasarana, karyawan sekolah, sebagian guru-guru yang telah diberi mandat, tata usaha sekolah, petugas kebersihan dan perawatan sekolah atau yang disebut dengan Office Boy selaku orang-orang yang berhaq mongoperasikan, merawat, serta melindungi kondisi sarana prasarana sekolah MAN 3 Banyuwangi.

Keterlibatan orang-orang yang telah dipercaya kepala sekolah tersebut seperti yang telah dijelaskan oleh bidang sara prasarana Ibu Nur Dwi Utami, S.Pd. mengatakan bahwa :

Kepemimpinan Kepala Madrasah Dalam Mengembangkan Sarana Prasarana MAN 3 Banyuwangi Eko Budiywono, Khoirul Fahmi Iskandar 
"Kepala sekolah dalam mengembangkan sarana prasarana MAN 3 Banyuwangi selalu melibatkan seluruh warga yang ada disekolah termasuk bidang sarana prasarana, guru-guru yang telah diberikan tugas atas haqnya terhadap sarana prasarana, tata usaha, dan petugas yang merawat sarana prasarana sekolah. Dengan cara mensosialisasikan situasi dan kondisi sarana prasana madrasah pada tahun ajaran ini. Karena mereka semua memiliki hak suara untuk mengembangkan sarana prasarana terkait dengan kondisi, kendala, atau masalah-masalah yang ada pada sekolah selama tahun ajaran ini berlangsung”.

Pada pernyataan yang telah disampaikan bidang sarana prasarana ini didukung oleh data hasil observasi dilapangan yang membuktikan bahwa, untuk ajaran ini pada tahun 2019, sekolah telah merenofasi keadaan sekolah yang semula keadaan cat tembok yang sudah harus diperbaiki, untuk ajaran ini sekolah melakukan pengecatan ulang serta mengganti warna sekolah sebelumnya yang semula berwarna hijau menjadi cat baru dengan berwarna kuning, meskipun kondisi saat ini ketika observasi dilakukan, kondisi sekolah belum sepenuhnya rampung dalam pengerjaan, akan tetapi peneliti sudah membuktikan bahwa, disetiap akhir tahun sekolah benar-benar melakukan perencanaan terhadap kondisi, keadaan sarana prasarana MAN 3 Banyuwangi. Untuk lebih lanjut melihat kondisi dekolah saat ini bisa dilihan dihalaman lampiran yang ada.

Terkait dengan pengecatan bidang bagian sarana prasarana Ibu Nur Dwi Utami, S.Pd. menjelaskan:

"Proses pengecatan ini dilakukan pada tahun ini, karena setelah melakukan musyawarah, para wewenang atas sarana prasarana sepakat bahwa, cat sekolah memang sudah harus diperbarui"”.

Dalam kondisi seperti ini, cat yang sudah terlihat kusam kemudian juga kondisi tembok yang sudah luntur, bidang sarana prasarana beserta pihak yang berwenang melakukan perawatan dan perbaikan disekolahnya sehingga, kondisi sekolah yang sudah kusam dapat kembali cerah, bersih, dan membuat nyaman semua orang yang ada disekolah.

Kepemimpinan Kepala Madrasah Dalam Mengembangkan Sarana Prasarana MAN 3 Banyuwangi

Eko Budiywono, Khoirul Fahmi Iskandar 
Namun untuk jangka cat sekolah tersebut bidang sarana prasarana Ibu Nur Dwi Utami, S.Pd. memaparkan:

"untuk pengecatan sekolah ini tidak mesti setahun sekali, kita melihat sesuai dengan keadaan yang ada dulu, kalo memang memungkinkan diperbaiki, ya kita perbaiki, tapi kalo menurut hasil pengamatan dan musyawarah yang ternyata sarana prasarana sekolah masih layak pakai, kita menundanya dulu, menunggu kondisi sarana prasarana memang betul-betul membutuhkan untuk diperbaiki”.

Dari pemaparan diatas memang sesuai dengan hasil observasi dilapangan. Ketika pada observasi awal, peneliti melihat sebelumnya bahwa, kondisi cat yang ada disekolah meang benar- benar perlu diperbaiki, dan ternyata ketika melihat pada ajar baru pada tahun ini, kondisi semula cat sudah diperbarui. tidak hanya kondisi cat saja, upaya pelebaran tempat ibadah yang menjadi wadah kegiatan peserta didik juga dilakukan pihak sekolah, dengan memindahkan ruang kreatifitas peserta didik yang semula bertempat disebelah musholla, untuk tahun ajaran baru ini, dipindahkan ketempat lain guna untuk memberikan tempat bagi peserta didik yang melakukakan kegiatan belajar keagamaan seperti sholat berjamaah. Meskipun dalam upaya ini, kondisi sekolah belum sepenuhnya memberikan kenyamanan terhadap peserta didik yang sedang sholat berjamaah yang mana telah memindahkan tempat kreatifitas siswa ketempat lain, ternyata kondisi belum bisa menampung para peserta didik dalam sholat berjamaah. Namun dalam permasalahan ini bidang sarana prasarana Ibu Nur Dwi Utami, S.Pd. memaparkan bahwa :

"Sekolah ini selalu melakukan perencanaan kebutuhan, seperti halnnya, upaya memperluas kondisi musholla, yang saat ini belum bisa menampung seluruh peserta didik dan dewan guru dalam kegiatan keagamaan seperti sholat jamaah, yang mana hal ini memilkiki masalah tentang kendala dana yang dimiliki, sehingga, kita harus menunggu kondisi dana yang sudah mencukupi sehingga dapat melangkah kepengembangan sarana prasarana selanjutnya yaitu ppelebaran musholla Man 3 Banyuwangi”.

Kepemimpinan Kepala Madrasah Dalam Mengembangkan Sarana Prasarana MAN 3 Banyuwangi

Eko Budiywono, Khoirul Fahmi Iskandar 
Menurut hasil observasi dilapangan, peneliti menemukan kondisi musholla yang memang membutuhkan penyusunan rencana kebutuhan, karena terlihat para dewan guru dan peserta didik dalam melakukan kegiatan keagamaan seperti sholat berjamaah kondisi muusholla sudah tidak dapat menampung keseluruhanya, sehingga para jamaah dari dewan guru dan peserta didik harus rela sholat hingga diluar musholla dengan rela berpanaspanasan ketika sholat dzuhur berlangsung dengan menggunakan fasilitas sekolah yakni tikar seadanya. Namun pada kondisi seperti ini, tidak sedikitpun menghilangkan semangat para peserta didik dalam melakukan kegiatan yang menjadi wadzifah pada setiap harinya.

Dari beberapa uraian diatas, dapat diambil kesimpulan bahwa, pihak kepala sekolah MAN 3 Banyuangi selalu melibatkan bawahanya dalam mengembangkan sarana prasarana sekolah dengan kegiatan Penyusuna rencana kebutuhan sekolah, sehingga besar biyaya yang dikeluarkan dapat diketahui sebelum melakukan kegiatan pengembangan sarana prasarana, sehingga setelah melakukan musyawarah dengan melibatkan orang-orang yang berhak terhadap sarana prasarana itu, pihak sekolah dapan meminimalisir bersarnya kekurangan dana dalam melakukan perawatan, penambahan, baik bangunan ataupun kebutuhan sarana prasarana lainya.

3. Perencanaan Pengadaan Sarana Prasarana MAN 3 Banyuwangi

Dalam penelitian ini, kepala madrasah memiliki peranan yang sangat penting dalam mengembangkan sekolah termasuk dalam bentuk strategi perencanaan pengadaan sarana prasarana.sesuai dari hasil wawancara terhadap bidang sarana prasarana oleh Ibu Nur Dwi Utami, S.Pd. beliau mengatakan bahwa:

"Setiap kepala sekolah pasti memiliki strategi untuk perencanaan pengadaan sarana perasarana sekolah, karena tugas kepala sekolah tersendiri salah satunya sebagai menejer yang didalamhnya harus memiliki program-program untuk mengembangkan sekolahnya, salah satunya memiliki strategi perencanaan pengadaan sarana prasarana".

Kepemimpinan Kepala Madrasah Dalam Mengembangkan Sarana Prasarana MAN 3 Banyuwangi

Eko Budiywono, Khoirul Fahmi Iskandar 
Adapun strategi perencanaan pengadaan kepala madrasah MAN 3 Banyuwangi tersebut yaitu dengan mengelola dana dari pemerintah dan dana dari infaq peserta didik atau pun wali murid. Dengan demikian pihak sekolah dapat mengembangkan serta memenuhi sarana prasarana sekolah sesuai dengan keinginan dan kebutuhan yang harus dipenuhi.

Hal ini sesuai dengan pertanyaan yang dikemukakan oleh pengelola sekolah bagian sarana prasarana MAN 3 Banyuwangi oleh Ibu Nur Dwi Utami, S.Pd. sebagai berikut:

"sarana prasarana itu memang harus dipenuhi jikalau sekolah menginginkan sekolahnya menjadi baik, dan yang pasti memerlukan dana yang cukup banyak, maka dari itu sekolah ini dalam mengembangkan sarana prasana menggunakan dana dari pemerintah yaitu dana APBN, akan tetapi kepala sekolah ini memiliki strategi dalam pengembanganya untuk memungkinkan kebutuhan sarana prasarana menjadi lebih baik yaitu melalui menerima jariyah dari siswa ataupun wali murid".

Selebihnya Ibu Nur Dwi Utami, S.Pd mengatakan bahwa dalam penerimaan jariyah infaq dari siswa itu pada setiap bulan sekali, sedangkan dari wali murid itu sendiri waktunya tidak ditentukan. Artinya bahwa pihak sekolah membuka selebar-lebarnya jikalau ada wali murid yang beramal jariyah untuk madrasahnya kapanpun waktunya, sehingga kebutuhan sarana prasarana dalam bentuk perawatan, penambahan, kemudian pemeliharaan, perbaikan ataupun membeli barang-barang baru yang diperlukan untuk membantu proses belajar mengajar peserta didik. Peran kepala madrasah MAN 3 Banyuwangi sebagai pemimpin yang memilki strategi pemikiran untuk mengembangkan sekolahnya sangat berperan dalam perencanaan pengembangan sarana prasarana khususnya dalam bentuk pengadaan sarana prasarana baik secara langsung ataupun tidak langsung seperti halnya pengadaan alat tulis didalam ruang kelas ataupun dikantor, pengadaan fasilitas belajar seperti bangku, meja, papan tulis, almari, pengadaan alat kebersihan, pengadaan buku-buku refrensi, dan alat elektronik seperti pengadaan alat media pembelajaran seperti CD atau DVD, Monitor, Kepemimpinan Kepala Madrasah Dalam Mengembangkan Sarana Prasarana MAN 3 Banyuwangi Eko Budiywono, Khoirul Fahmi Iskandar 
Komputer dikantor atau dilaboratorium sekolah, bahkan madrasah MAN 3 Bayuwangi memiliki saraana prasarana yang unik yang tidak selalu dimiki oleh sekolah-sekolah lain yaitu adanya CC TV disetiap ruang baik kelas, kantor, ruang guru, ruang tata usaha, perpustakaan, musholla, ma'had, bahkan disetiap titik-titik diluar ruangan seperti didepan gerbang sekolah, didepan kelas, didepan kantor, didepan musholla, didepan ma'had, didepan WC umum, tempat parkir, dan lapangan tempat olahraga.

Hal tersebut sesuai dari pemaparan bidang sarana prasarana oleh Ibu Nur Dwi Utami, S.Pd mengatakan bahwa:

"adanya pengadaan sarana prasarana ini juga atas arahan serta himbauan kepala sekolah, karena kepala sekolah tersendiri memiliki hak priogratifnya untuk memiliki strategi pengembangan sarana prasarana".

Namun, dalam mengembangkan sarana prasarana tersendiri tidak hanya dilakukan kepala sekolah saja, akan tetapi juga melibatkan bawahan atau karyawan sekolah. Khususnya oleh bidang sarana prasarana. Seperti yang telah diutarakan bidang sarana prasarana pada wawancara terhadap Ibu Nur Dwi Utami, S.Pd mengenai tugas sarana prasarana yaitu:

“ Tugas sarana prasarana tersendiri yaitu fokus membantu kepala sekolah dalam pengadaan, pengembangan, perawatan sarana prasarana, dan juga sarana prasarana memilki program seperti guru-guru yang lainya, sebagai contoh guru mata pelajaran AL Qur'an Hadits, sebelum mengajar pasti memilki program kedepanya baik bentuk RPP atau pun tekhnik dalam mengajar dikelas. Begitu pula bidang sarana prasarana memiki program dalam betugas sebagai mana mestinya".

Selain beberapa dokumen hasil wawancara dan observasi diatas, penulis juga memperlihatkan beberapa potret hasil observasi diMAN 3Banyuwangi terkait pengadaan pengembangan sarana prasarana, dan jika ingin mengetahui dan melihat lebih lengkap, bisa langsung dilihat di halaman lampiran

Kepemimpinan Kepala Madrasah Dalam Mengembangkan Sarana Prasarana MAN 3 Banyuwangi Eko Budiywono, Khoirul Fahmi Iskandar 


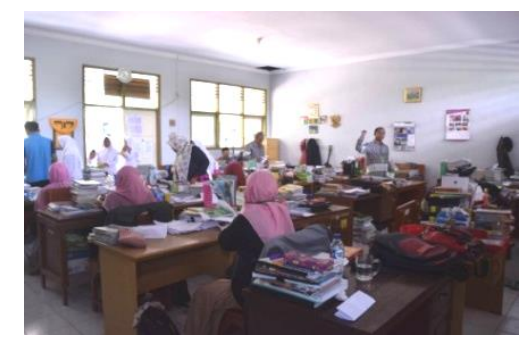

Gambar 1 Ruang Tata Usaha

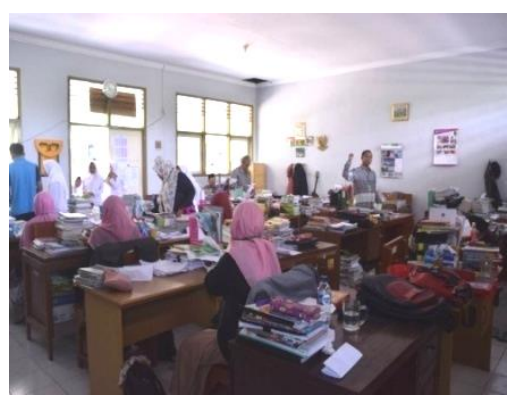

Gambar 3 Ruang Guru

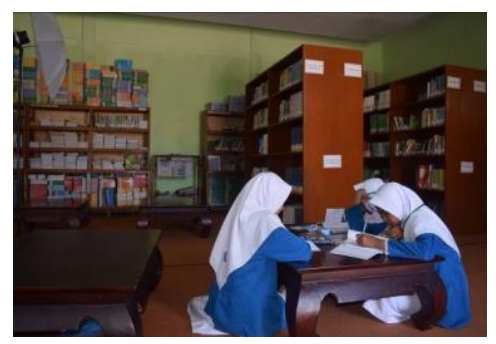

Gambar 2 Ruang Guru

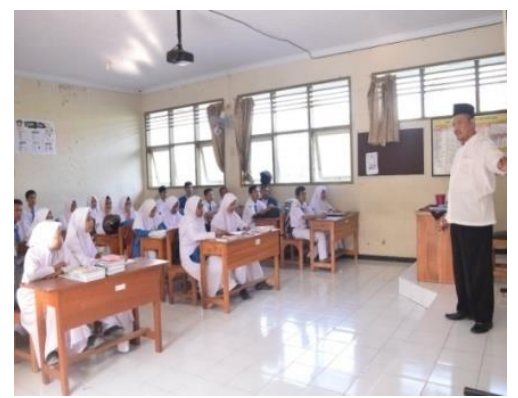

Gambar 4 Ruang Kelas

Pada gambar 1 merupakan potret ruangan perpustakaan MAN 3 Banyuwangi. Perpustakaan itu dapat digunakan kondisional tergantung peraturan jadwal yang telah ditentukan oleh pihak sekolah. Seperti pada ajaran baru ini, perpustakaan dijadikan sementara ruangan kelas untuk peserta didik baru karena kurangnya ruangan kelas yang kurang. Sementara itu pada gambar 2 terdapat ruang tata usaha yang berfungsi sebagai wadah pusat pelayanan, informasi dan pelaksana teknis administrasi sekolah. Sedangkan pada gambar 3 terdapat ruangan guru yang berfugsi sebagai tempat peristirahatan dewan guru, tempat guru dalam melaksanakan tugas sekolah, dan tempat guru mempersiapkan proses belajar mengajar dikelas. Pada gambar 4 ruangan tersebut merupakan tempat dimana peserta didik belajar, pada tempat itu sudah diengkapi sarana prasarana yang mencukupi, mulai dari kursi, meja, alat tulis, papan tulis, serta alat elektronik yang membantu proses belajar mengajar yaitu monitor yang digunakan guru ketika memerlukan suatu presentasi yang membutuhkan gambar, dan tidak kalah menarik dengan sekolah-sekolah lain, dipojok ruangan setiap kelas pada madrasah MAN 3 Kepemimpinan Kepala Madrasah Dalam Mengembangkan Sarana Prasarana MAN 3 Banyuwangi Eko Budiywono, Khoirul Fahmi Iskandar 
Banyuangi itu terdapat CC TV yang digunakan kepala sekolah dalam mengawasi, membina, mengingatkan proses belajar mengajar eserta didiknya melalui alat pengeras suara yang ada dimadrasah.

Akan tetapi pada ruangan kelas tersebut termasuk belum mencukupi standart sarana prasarana menurut bidang sarpras Ibu Nur Dwi Utami, S.Pd yaitu:

“ Kalo sarana prasarana disini Insya Alloh sudah termasuk baik, akan tetapi pada beberapa ruangan yang ada dimadrasah MAN 3 Banyuwangi ini, masih jauh terbilang standar menurut peraturan pemerintah".

Dari beberapa uraian yang telah dipaparkan diatas, strategi perencanaan dan pengembangan sarana prasarana madrasah sudah termasuk baik meskipun jauh dari standar madrasah. Salah satu penyebab daripada beberapa sarana prasarana sekolah yaitu dana yang dimiki oleh pihak sekolah masih tergolong terbatas, sehingga seluruh kebutuhan memerlukan strategi kepala sekolah yang khusus demi mewujudkan impian sekolah dalam mengembangkan sarana prasana. Seperti yang dipaparkan bidang sarana prasarana oleh Ibu Nur Dwi Utami, S.Pd yaitu:

"Untuk dana pengembangan sarana prasarana dari sekolah kalo dibilang kurang ya kurang, karena melihat kebutuhan kita sangatlah banyak, akan tetapi tidak imbang dengan kebutuhan yang ada, sehingga memerlukan strategi kepala madrasah khusus untuk mengatasi masalah ini".

Strategi khusus yang dilakukan kepala madrasah yaitu dengan infaq peserta didik seperti yang telah diuraikan diatas, akan tetapi pada infaq ini diwajibkan kepada semua peserta didik pada awal bulan disetiap bulanya. Kemudian juga didapatkan pada awal pembukaan peserta didik baru setelah melakukan pendaftaran dan registrasi sekolah. Selain itu termasuk dari strategi kepala madrasah dalam mengembangkan sarana prasana adalah menciptakan unit kegiatan usaha seperti kantin sekolah, sehingga hasil dari kantin sekolah tersebut dapat digunakan untuk memenuhi kekurangan dana dari pemerintah untuk madrasah MAN 3 Banyuwangi.

Kepemimpinan Kepala Madrasah Dalam Mengembangkan Sarana Prasarana MAN 3 Banyuwangi

Eko Budiywono, Khoirul Fahmi Iskandar 


\section{E. Pembahasan}

\section{Sarana Prasarana MAN 3 Banyuwangi}

Pada kondisi sarana prasarana madrasah saat ini sudah tergolong baik dan mencukupi kebutuhan sarana prasarana, akan tetapi hanya beberapa kondisi sarana prasarana seperti kurangnya bangku sekolah, ketidakmuatan musholla dan ruang kelas karena tidak dapat menampung banyaknya peserta didik yang ada. Adapun untuk melakukan penyusunan perencanaan kebutuhan sarana prasarana tidak dilakukan semua orang yang ada disekolah MAN 3 Banyuwangi, akan tetapi dilakukan oleh orang-orang yang berhak terhadap sarana prasarana yaitu kepala sekolah dengan dibantu karyawan orang-orang yang sudah diberi kewenangan terhadap sarana prasarana seperti bidang sarana prasarana, karyawan guru sebgian saja yang telah diberikan tugas mengenai pengadaan dan perawata sarana prasarana, tata usaha, dan petugas Office Boy yang dilakukukan setiap akhir tahun dari tahun ajaran sekolah. Sehingga dengan berjalanya perencanaan kebutuhan sarana prasarana kebutuhan sekolah dapat didapatkan dan mendapatkan kegiatan sesuai harapan.

Mengenai kelengkapan yang dimiliki madrasah terkait sarana prasarana masih jauh dari standarisasi pemerintah terhadap sarana prasarana, akan tetapi kelengkapan sarana prasarana pada elektronik MAN 3 Banyuwangi memilki hal keunikan seperti disetiap titik dan ruangan baik kelas dalam belajar mengajar maupun kantor memilkiki kamera tersembunyi atau CC TV sehingga proses kegiatan serta kelancaran belajar dapat terlihat dan terkontrol oleh manajer sekolah atau kepala madrasah MAN 3 Banyuwangi. Seperti pada Lembaga pendidikan pada umumnya yang menyediakan layanan pendidikan kepada masyarakat, Madrasah Aliyah Negeri 3 Banyuwangi, Srono Kabupaten Banyuwangi telah dilengkapi dengan sarana dan prasarana yang belum memadai. Sehingga ketersediaan dan kondisi Sarana Prasarana Pendidikan pada Madrasah Aliyah Negeri Srono Kabupaten Banyuwangi.

2. Kepemimpinan Kepala Madrasah Dalam Mengembangkan Sarana Prasarana

Kepemimpinan Kepala Madrasah Dalam Mengembangkan Sarana Prasarana MAN 3 Banyuwangi

Eko Budiywono, Khoirul Fahmi Iskandar 
Kepala madrasah dalam mengembangkan sarana prasarana seperti kondisi ruang kelas dan kondisi musholla perlu ditingkatkan, karena pada tahun ketahun kondisi siswa menjadi lebih banyak apalagi terhadap sekolah yang sudah menjuarai akreditasi sebagai juara 1 ditingkat profinsi jawa timur, tentu akan menjadikan peminat pada masyarakat yang begitu pesat, sehingga perencanaan terhadap jumlah dan besarnya musholla yang masih belum mencukupi, menjadikan kondisi saat ini menjadi masih kurang, sehingga membutuhkan perencanaan dengan mengelola dana dari pemerintah dan dana dari infaq peserta didik atau pun wali murid. Dengan demikian pihak sekolah dapat mengembangkan serta memenuhi sesuai dengan keinginan dan kebutuhan yang harus dipenuhi terhadap sarana prasarana MAN 3 Banyuwangi.

3. Faktor Pendukung Kepemimpinan Kepala Madrasah Dalam Mengembangkan Sarana Prasarana.

Dalam mengembangkan sarana prasarana sekolah, pihak yang berwenang memilki langkah dalam menjaga dan merawat sarana prasarana yang ada, dengan melakukan pengecekan dalam setiap satu minggu sekali oleh pihak yang bertugas dan menerima laporan dari berbagai pihak baik dari dewan guru, karyawan bahkan siswa untuk melaporkan kerusakan atau kondisi sarana prasarana yang perlu diganti, sehingga dalam menggunakan sarana prasarana selalu menjadikan kelancaran dalam proses belajar mengajar tanpa hambatan suatu apapun. Dengan demikian, pihak-pihak tersebut menjadi faktor untuk menduung strategi kepala madrasah dalam mengembangkan sarana prasarana.

4. Faktor Penghambat Kepemimpinan Kepala Madrasah Dalam Mengembangkan Sarana Prasarana.

Karena anggaran yang dimiliki sekolah yang sangat terbatas, menjadikan pengelolaan dan pengembangan sarana prasarana menjadi hambatan dan masalah besar untuk pihak sekolah, sehingga terbatasnya anggaran tersebut menuntut kepala sekolah memilki strategi khusus dalam mengembangkan sarana prasarana sekolah. Maka dari itu strategi yang dimilki kepala sekolah Kepemimpinan Kepala Madrasah Dalam Mengembangkan Sarana Prasarana MAN 3 Banyuwangi Eko Budiywono, Khoirul Fahmi Iskandar 
untuk memenuhi kebutuhan sarana prasarana atas kondisi keuangan yang terbatas dengan mengadakan infaq oleh peserta didik, wali murid atau siapapun yang ingin beramal baik untuk sekolah. Selain itu strategi kepala sekolah dalam mengembangkan sarana prasarana MAN 3 Banyuwangi dengan menciptakan usaha keuangan dalam bentuk kantin yang dimiliki sekolah, sehingga hasil dari unit usaha tersebut dapat membantu dari kekurangan anggaran yang dimilki seklah dari pemerintah.

\section{F. Kesimpulan}

1. Sarana prasarana madrasah saat ini sudah tergolong baik dan mencukupi kebutuhan sarana prasarana, akan tetapi hanya beberapa kondisi sarana prasarana seperti kurangnya bangku sekolah, ketidakmuatan musholla dan ruang kelas karena tidak dapat menampung banyaknya peserta didik yang ada.

2. Kepemimpinan yang dimiliki kepala madrasah dalam mengembangkan sarana prasarana seperti kondisi ruang kelas dan kondisi musholla adalah merencanakan secara intensif dengan mengelola dana dari pemerintah dan dana dari infaq peserta didik atau pun wali murid. Dengan demikian pihak sekolah dapat mengembangkan serta memenuhi sesuai dengan keinginan dan kebutuhan yang harus dipenuhi terhadap sarana prasarana MAN 3 Banyuwangi.

3. Faktor Pendukung dalam mengembangkan sarana prasarana sekolah, kepala sekolah dan bidang prasarana memilki kebijakan penuh dalam mengembangkan, menjaga dan merawat sarana prasarana yang ada serta kerjasama seluruh elemen dewan guru, karyawan bahkan siswa. Sedangkan Faktor Penghambatnya karena anggaran yang dimiliki sekolah yang sangat terbatas, menjadikan pengelolaan dan pengembangan sarana prasarana menjadi hambatan dan masalah besar untuk pihak sekolah, sehingga terbatasnya anggaran tersebut menuntut kepala sekolah memilki strategi khusus dalam mengembangkan sarana prasarana sekolah.

Kepemimpinan Kepala Madrasah Dalam Mengembangkan Sarana Prasarana MAN 3 Banyuwangi

Eko Budiywono, Khoirul Fahmi Iskandar 


\section{G. Daftar Pustaka}

Baidu, Q., Syamsu. \& Djafri. Noviyanti. 2017. Kepemimpinan Dan Prilaku Organisasi. Gorontalo: Ideas Publishing.

Barnawi, \& Arifin, M. 2016. Manajemen Sarana Prasarana Sekolah. Yogyakarta: Ar Ruzz Media.

Margono, E., Mulyasa. Menjadi Kepala Sekolah Profesional. Bandung: PT Remaja Posdakarya.

Matin, Nur. 2016. Manajemen Sarana Dan Prasarana Pendidikan: Konsep Dan Aplikasinya. Jakarta: PT Raja Grafindo.

Mulyasa. 2013. Manajemen Kepemimpinan Kepala Sekolah. Jakarta: Bumi Aksara.

Permadi, D., Arifin, D., 2007. Kepemimpinan Dan Transformasi Kepala Sekolah Dan Komite Sekolah. Bandung: PT Sarana Panca Karya Nusa.

Permadi, D., 2001. Manajemen Berbasis Sekolah Dan Kepemimpinan Mandiri Kepala Sekolah. Bandung: PT Sarana Panca Karya Nusa.

Permendiknas No 24 Tahun 2007 tentang standar sarana prasarana untuk madrasah.

Sri Ambar, Wahyu. 2007. Manajemen Sarana Prasarana Pendidikan. Jakarta: CV Karya Mulia.

Sugiyono. 2011. Metode Penelitian Kuantitatif Kualitatif Dan R\&D. Bandung: PT Alfabeta.

Sumidjo, Wahjo. 2010. Kepemimpinan Kepala Madrasah. Jakarta: PT Raja Grafindo Persada.

Kepemimpinan Kepala Madrasah Dalam Mengembangkan Sarana Prasarana MAN 3 Banyuwangi

Eko Budiywono, Khoirul Fahmi Iskandar 